\title{
PENGARUH MODEL PEMBELAJARAN KOOPERATIF TIPE TEAMS GAMES TOURNAMENT (TGT) TERHADAP HASIL BELAJAR IPA SISWA KELAS VIII SMP DITINJAU DARI KERJASAMA SISWA
}

\author{
(THE EFFECT OF COOPERATIVE LEARNING-TEAM GAMES TOURNAMENT (TGT) TO THE \\ SCIENCE RESULT OF VIII GRADE IN JUNIOR HIGH SCHOOL WHICH IS OBSERVED BY \\ STUDENTS' COOPERATION)
}

\author{
Zahrina Ismah, Tias Ernawati* \\ Program Studi Pendidikan IPA FKIP Universitas Sarjanawiyata Tamansiswa, Yogyakarta \\ *Email: tias.ernawati@ustjogja.ac.id
}

Diterima: 15 Desember 2017. Disetujui: 28 Maret 2018. Dipublikasikan: 31 Maret 2018

\begin{abstract}
Abstrak: Penelitian bertujuan untuk mengetahui pengaruh penggunaan model pembelajaran kooperatif tipe Teams Games Tournament (TGT) terhadap hasil belajar IPA siswa kelas VIII SMP N 3 Kasihan ditinjau dari kerjasama siswa. Objek penelitian ini adalah hasil belajar IPA siswa. Penelitian ini adalah quasi eksperiment. Teknik pengumpulan data menggunakan teknik tes, teknik angket, dan teknik dokumentasi. Instrument tes berupa soal pilihan ganda yang berjumlah 30 soal dan instrumen angket berupa pernyataan yang berjumlah 20 butir. Hasil perhitungan diperoleh $\mathrm{F}_{\text {hitung }}=9,315$ dengan $\mathrm{p}=0,004$ dan rerata hasil belajar sebesar 20,192, rerata hasil angket sebesar 77,846. Uji hipotesis menunjukkan ada perbedaan hasil belajar siswa yang pembelajarannya menggunakan model TGT dan ekspositori. Berdasarkan rerata hasil belajar dan hasil angket, maka dapat ditarik kesimpulan bahwa ada pengaruh penggunaan model pembelajaran kooperatif tipe TGT terhadap hasil belajar IPA siswa kelas VIII di tinjau dari kerjasama siswa.
\end{abstract}

Kata Kunci: TGT, IPA, Kerjasama.

\begin{abstract}
This research is aimed to know the impact of using a cooperative learning model in type Teams Games Tournament (TGT) toward the result of learning sciences for student in VIII grade of SMP N 3 Kasihan which is observed by the student's cooperation. The object of this research is the students' natural science achievements. This research is a quasi experiment. The data were collected by test, questioner and documentation techniques. Instrument test is consisting of 30 multiple-choices questions, and questioner instrument is containing with 20 statements. As the result, the researcher obtained $F_{h}=9,315$ and $p=0,004$, the average of learning result is 20,192 , the average of questioner is 77,846 . The hypotesis test shows there is contradiction of students' achievements who are tought by TGT and expository. Based on the average of learning result and questioner, then there is an impact by using a cooperative learning model in type Teams Games Tournament (TGT) toward the result of learning sciences for student in class VIII which is observed by the students' cooperation.
\end{abstract}

Keywords: TGT, science, cooperation

\section{PENDAHULUAN}

Pendidikan penting dalam menciptakan manusia-manusia berkualitas. Pendidikan memerlukan inovasi-inovasi yang seiring dengan kemajuan ilmu pengetahuan dan teknologi dengan tidak mengabaikan nilai-nilai kemanusiaan. Upaya untuk membentuk manusia yang cerdas/berilmu dan berkualitas serta berkepribadian baik adalah bagian dari misi pendidikan yang menjadi tanggung jawab profesional setiap guru. Guru dengan sadar merencanakan kegiatan pembelajaran secara sistematis dan berpedoman pada seperangkat aturan dan rencana tentang pendidikan yang disebut sebagai kurikulum.

Hasil observasi di sekolah menunjukkan bahwa beberapa proses pembelajaran IPA tidak bannyak melibatkan siswa, sehingga siswa kurang kreatif. Masih banyak guru yang menggunakan model pembelajaran yang konvensional dimana guru sebagai pusat informasi menerangkan materi dan siswa duduk dengan manis mendengarkan dan mencatat materi yang disampaikan oleh guru, sehingga siswa menjadi pasif dan tidak kreatif. Minat belajar siswa rendah, motivasi kurang dan berujung pada hasil belajar yang rendah. Tidak banyak kesempatan bertanya dan berdiskusi dengan leluasa. Kerjasama siswa tidak terjalin dengan baik. Model pembelajaran kooperatif tidak terlaksana dengan baik.

Pendidikan IPA sebagai bagian dari pendidikan umumnya memiliki peran penting dalam peningkatan mutu pendidikan, khususnya di dalam menghasilkan peserta didik yang berkualitas, yaitu 
manusia yang mampu berfikir kritis, kreatif, logis dan berinisiatif dalam menanggapi isu di masyarakat yang diakibatkan oleh dampak perkembangan IPA dan teknologi. Pendidikan IPA juga diharapkan dapat menjadi wahana peserta didik untuk mempelajari diri sendiri dan alam sekitar, serta prospek pengembangan lebih lanjut dalam menerapkannya di dalam kehidupan sehari-hari. Proses pembelajaran IPA menekankan pada pemberian pengalaman langsung untuk mengembangkan kompetensi agar menjelajahi dan memahami alam sekitar secara ilmiah[4].

Rendahnya hasil belajar IPA siswa dapat disebabkan usaha yang dilakukan guru untuk meningkatkan hasil belajar siswa belum berjalan seperti yang diharapkan. Banyak usaha yang dapat dilakukan untuk memperbaiki kualitas pendidikan, diantaranya pembaharuan kurikulum, proses belajar mengajar, peningkatan kualitas guru, pengadaan buku pelajaran, sarana belajar mengajar, penyempurnaan sistem penilaian dan sebagainya. Berhasil tidaknya pencapaian tujuan pendidikan sangat dipengaruhi keberhasilan proses belajar mengajar.

Model pembelajaran kooperatif Teams Games Tournament (TGT) menjadi pilihan dalam proses belajar mengajar. Dalam TGT, satu kelompok terdiri dari 3 siswa yang memiliki kemampuan heterogen (rendah, sedang, dan tinggi)[5]. Hasil belajar IPA dengan permainan yang dirancang dalam model ini memungkinkan siswa dapat belajar lebih rileks di samping menumbuhkan tanggung jawab, kerja sama, persaingan sehat, dan keterlibatan belajar. Ada 5 komponen utama dalam TGT yaitu presentasi di kelas, tim (kelompok), game (permainan), turnamen, dan rekognisi tim [10]. Model ini dapat mengubah pembelajaran yang semula teacher oriented ke student oriented. Beberapa manfaat penerapan model TGT antara lain: 1)siswa memiliki kebebasan untuk berinteraksi dan mengungkapkan pendapatnya; 2)Rasa percaya diri siswa menjadi lebih tinggi; 3)Perilaku saling mengganggu antar siswa menjadi berkurang; 4)Motivasi belajar siswa bertambah; 5)Kepekaan dan toleransi antar siswa akan meningkat; 6)Kebebasan mengaktualisasikan diri dengan seluruh potensi yang ada pada diri siswa serta meningkatkan kerjasama dengan siswa lain sehingga interaksi belajar mengajar dalam kelas menjadi hidup dan tidak membosankan.

Astuti Wijayanti [11] dalam penelitiannya menyebutkan bahwa model pembelajaran TGT dapat meningkatkan pemahaman konsep dan partisipasi mahasiswa Pendidikan IPA. Secara umum proses pembelajaran yang menggunakan model pembelajaran TGT berjalan dengan lancar dan mengalami peningkatan di setiap siklusnya. Sehingga pembelajaran dengan model TGT dapat meningkatkan minat dan prestasi belajar matematika siswa [9]. Senada dengan hal tersebut, penerapan model pembelajaran kooperatif tipe TGT dengan bantuan permainan puzzle pada mata pelajaran IPS dapat meningkatkan hasil belajar yang dapat dibuktikan dengan ketuntasan nilai IPS pada siklus I dan Siklus II [2]. Di lain pihak, kemampuan pemahaman konsep matematika siswa yang menggunakan model pembelajran kooperatif TGT lebih baik dari model pembelajaran kooperatif tipe Student Teams Achievement Division (STAD) di SD Islam Khalifah Annizam [7].

Salah satu aspek dalam pembelajaran kooperatif adalah kerjasama atau kooperasi. Kerjasama mengharuskan siswa berinteraksi dengan temannya. Interaksi yang terjalin dengan baik akan lebih mempermudah siswa dalam menerima materi yang disampaikan oleh guru. Dengan kata lain kerjasama siswa menentukan berhasil tidaknya penggunaan model pembelajaran kooperatif yang nantinya akan berpengaruh terhadap hasil belajar siswa itu sendiri. Menurut Narwoko dan Suyanto[8] kooperasi (kerjasama) berasal dari dua kata latin, co yang berarti bersama-sama dan operani yang berarti bekerja. Kerjasama merupakan perwujudan minat dan perhatian orang untuk bekerja bersama-sama dalam suatu kesepahaman, sekalipun motifnya seiring dan bisa tertuju kepada kepentingan diri sendiri.

Dalam penelitian ini penulis berharap dapat: 1)mengetahui kecenderungan hasil belajar IPA siswa yang pembelajarannya menggunakan model pembelajaran kooperatif tipe TGT; 2) Untuk mengetahui kecenderungan hasil belajar IPA siswa yang pembelajarannya menggunakan model ekspositori; 3) mengetahui kecenderungan kerjasama siswa yang pembelajarannya menggunakan model pembelajaran TGT; 4) mengetahui kecenderungan kerjasama siswa yang pembelajarannya menggunakan model pembelajaran ekspositori; 5) perbedaan hasil belajar IPA siswa antara yang menggunakan model pembelajaran kooperatif tipe TGT dengan model pembelajaran ekspositori ditinjau dari kerjasama siswa.

\section{METODE PENELITIAN}

Penelitian ini adalah quasi eksperimen. Desain penelitian menggunakan Factorial Design yang melibatkan dua atau lebih variabel bebas, dan sekurangnya satu yang dimanipulasi peneliti. Variabel yang digunakan dalam penelitian ini ada 3 yakni variabel terikat (Y) hasil belajar, variabel bebas (A) model pembelajaran, dan variabel kontrol (X) kerjasama siswa.

Populasi dalam penelitian ini adalah siswa kelas VIII SMP Negeri 3 Kasihan Bantul. Dari 5 kelas yang ada diambil 2 kelas secara random sebagai sampel. Pengumpulan data menggunakan teknik tes, teknik angket, dan teknik dokumentasi. Teknik tes digunakan untuk mengumpulkan data hasil belajar IPA. Teknik angket digunakan untuk 
mengumpulkan data kerjasama siswa. Sedangkan teknik dokumentasi untuk mengumpulkan data nilai awal siswa. Untuk menganalisa data secara deskritif, yang perlu dicari terlebih dahulu adalah skor terendah, skor tertinggi, rata-rata dan simpangan baku dari setiap variabel dan kemudian dibandingkan dengan kurva normal ideal sesuai ketentuan kurva normal ideal Azwar [3].

Penelitian ini menggunakan uji validitas korelasi Product Moment Pearson untuk butir tes dan butir angket, uji reliabilitas pada instrumen tes menggunakan rumus KR2O dan uji reliabilitas Alpha Cronbach's, dengan menggunakan bantuan program SPS edisi Sutrisno Hadi dan Yuni Pamardiningsih. Teknik analisis data menggunakan uji anakova yang diawali dengan uji prasyaratan analisis yaitu uji normalitas sebaran (Chi Kuadrat), uji homogenitas (uji F) dan uji linieritas hubungan (uji Fischer).

\section{HASIL PENELITIAN DAN PEMBAHASAN}

Dari hasil penelitian ini diperoleh skor rata-rata tes hasil belajar IPA siswa yang pembelajarannya menggunakan model pembelajaran kooperatif tipe Teams Games Tournament (TGT) adalah 20,192, sedangkan skor rata-rata tes hasil belajar IPA yang pembelajarannya menggunakan model pembelajaran ekspositori adalah 15,308. Perbedaan skor rata-rata hasil belajar IPA tersebut disebabkan karena siswa yang pembelajarannya menggunakan model pembelajaran kooperatif tipe Teams Games Tournament (TGT) akan lebih mudah memahami permasalahan IPA dan pemahaman siswa terhadap materi pembelajaran menjadi lebih baik. Kelebihan model pembelajaran kooperatif tipe Teams Games
Tournament (TGT) adalah siswa memiliki kebebasan untuk berinteraksi dan mengungkapkan pendapatnya, rasa percaya diri siswa menjadi lebih tinggi, Perilaku saling mengganggu antar siswa menjadi berkurang, Motivasi belajar siswa bertambah.. Sedangkan dalam pembelajaran yang menggunakan model pembelajaran ekspositori, guru lebih banyak mendominasi dalam proses pembelajaran dan siswa cenderung pasif sehingga dalam proses pembelajaran siswa menjadi bosan dan tidak tertarik. Dengan demikian siswa akan mengalami kesulitan dalam memahami pokok bahasan yang diajarkan.

Dari analisis skor posttest kelas eksperimen diperoleh data: Skor tertinggi $=26$, Skor terendah $=$ 11 , rerata $=20,19$ dan simpangan baku $=4,47$. Dengan memperhatikan tabel 1, maka skor rerata kelompok terletak pada interval $19,489 \leq \overline{\mathrm{X}} \leq 26$ yang termasuk dalam kategori sangat tinggi. Hasil analisis skor posttest kelas kontrol diperoleh data: Skor tertinggi $=23$, Skor terendah $=8$, rerata $=15,31$ dan simpangan baku $=4,29$. Berdasarkan nilai rerata maka hasil belajar siswa kelas kontrol termasuk dalam kategori tinggi.

Tabel 1. Uji Linieritas Hubungan Kerjasama Siswa dan Hasil Belajar IPA

\begin{tabular}{ccc}
\hline Kelompok & $\mathrm{F}_{\text {hitung }}$ & $\mathrm{P}$ \\
\hline Hubungan Kerjasama Siswa & \multirow{2}{*}{1,326} & 0,2 \\
dan Hasil Belajar IPA & & 54 \\
\hline
\end{tabular}

Tabel 2. Ringkasan Hasil Analisis Kovarian Pengaruh TGT terhadap hasil belajar ditinjau dari kerjasama siswa

\begin{tabular}{lccrrc}
\hline \multicolumn{1}{c}{ Kelompok } & JK & db & RK & F & P \\
\hline $\begin{array}{l}\text { Pengaruh TGT terhadap } \\
\text { hasil belajar ditinjau dari } \\
\text { kerjasama siswa }\end{array}$ & 182,327 & 1 & 182,327 & 9,315 & 0,004 \\
\hline
\end{tabular}

Dari analisis skor angket kerjasama siswa kelas eksperimen diperoleh data: Skor tertinggi $=$ 95, Skor terendah $=68$, rerata 77,85 dan simpangan baku sebesar 6,34. Dengan memperhatikan tabel 4, maka kerjasama kelas eksperimen termasuk kategori tinggi. Sedangkan skor angket kelas kontrol didapat data sebagai berikut; Skor tertinggi $=81$, Skor terendah $=53$, rerata 67,19 dan simpangan baku sebesar 7,66. Jadi kerjasama siswa untuk kelompok penggunaan model pembelajaran ekspositori termasuk kategori tinggi.

Berdasarkan perhitungan linieritas pada Tabel 1 diperoleh hasil $\mathrm{F}_{\text {hitung }}$ sebesar 1,326 dengan $\mathrm{p}=$ 0,254 . Karena $p \geq 0,05$ maka hubungan antara kerjasama siswa dan hasil belajar IPA bersifat linier. Tabel 2 menunjukkan ringkasan Hasil
Analisis Kovarian diperoleh hasil $\mathrm{F}_{\text {hitung }}=9,315$ dengan $\mathrm{p}=0,004$. Dari data tersebut diperoleh $p \leq 0,01$, maka hipotesis diterima. Ada perbedaan yang sangat signifikan hasil belajar IPA siswa kelas VIII antara yang menggunakan model pembelajaran kooperatif tipe TGT dengan model pembelajaran ekspositori ditinjau dari kerjasama siswa.

Dalam penelitian ini juga mengamati sikap kerjasama siswa. Dari hasil penelitian ini diperoleh skor rata-rata kerjasama siswa yang pembelajarannya menggunakan model pembelajaran kooperatif tipe Teams Games Tournament (TGT) adalah 77,846, sedangkan skor rata-rata kerjasama siswa yang pembelajarannya menggunakan model pembelajaran ekspositori 
adalah 67,192. Perbedaan skor rata-rata kerjasama siswa tersebut disebabkan karena siswa yang pembelajarannya menggunakan model pembelajaran kooperatif tipe Teams Games Tournament (TGT) lebih menekannkan pada kegiatan kelompok. Sedangkan untuk model pembelajaran ekspositori hanya mengandalkan apa yang disampaikan oleh guru sehingga siswa menjadi pasif dan interaksi dengan sesama temannya menjadi kurang. Model pembelajaran yang lebih didominasi oleh guru maka akan sulit mengembangkan kemampuan siswa dalam hal kemampuan sosialisasi, hubungan interpersonal, serta kemampuan berpikir kritis

Penelitian ini mendukung hasil penelitian yang dilakukan oleh Afifah dan Afniyanti [6] yang menyebutkan bahwa ada pengaruh model pembelajaran kooperatif tipe Teams Games Tournament (TGT) terhadap hasil belajar Biologi siswa kelas X SMA Negeri 1 Kepenuhan Kabupaten Rokan Hulu. Senada dengan penelitian yang dilakukan oleh Safarina [1] juga menyatakan bahwa terdapat pengaruh penggunaan model pembelajaran Teams Games Tournament (TGT) terhadap kerjasama siswa.

\section{KESIMPULAN}

Berdasarkan hasil penelitian dapat disimpulkan bahwa 1) kecenderungan hasil belajar IPA siswa yang pembelajarannya menggunakan model pembelajaran kooperatif tipe TGT berada pada kategori sangat tinggi; 2) kecenderungan hasil belajar IPA siswa yang pembelajarannya menggunakan model ekspositori berada pada kategori tinggi; 3) kecenderungan kerjasama siswa yang pembelajarannya menggunakan model pembelajaran TGT berada pada kategori tinnggi; 4) kecenderungan kerjasama siswa yang pembelajarannya menggunakan model pembelajaran ekspositori berada pada kategori tinggi; 5) ada perbedaan hasil belajar IPA siswa antara yang menggunakan model pembelajaran kooperatif tipe TGT dengan model pembelajaran ekspositori ditinjau dari kerjasama siswa sehingga dapat dikatakan ada pengaruh model pembelajaran kooperatif tipe Teams Games Tournament (TGT) terhadap hasil belajar IPA ditinjau dari kerjasama siswa

\section{REFERENSI}

[1] Safarina, E. I. (2018). Pengaruh Model Pembelajaran Kooperatif TGT Terhadap Hasil Belajar IPA Ditinjau Dari Kemampuan Kerjasama. Natural: Jurnal Ilmiah Pendidikan IPA, 5(1), 32-37.

[2] Ardi, Arga Nattha dan Harjono, Nyoto. 2007. Meningkatkan Keaktifan Dan Hasil Belajar IPS Model Team Game Tournament SD
Negeri 2 Kaligentong. Wacana Akademika $1(1): 37-46$.

[3] Azwar, Saifudin. 2013. Reliabilitas dan Validitas Edisi 4. Yogyakarta: Pustaka Pelajar.

[4] Depdiknas. 2008. Panduan Pengembangan Pembelajaran IPA Terpadu. Jakarta: Puskur, Balitbang Depdiknas.

[5] Huda, Miftahul. 2013. Model-model Pengajaran dan Pembelajaran.Yogyakarta: Pustaka Pelajar.

[6] Afifah, N., \& Afniyanti, E. (2015). Pengaruh Model Pembelajaran Kooperatif Tipe Team Games Tournament (TGT) Terhadap Hasil Belajar Biologi Siswa Kelas X SMA N 1 Kepenuhan Kabupaten Rokan Hulu Tahun Pembelajaran 2014/2015. Jurnal Ilmiah Mahasiswa FKIP Prodi Biologi, 1(1).

[7] Menanti, Hotmaria S. dan Aulia, Arief R. 2015. Perbandingan Kemampuan Pemahaman Konsep Matematika Siswa Menggunakan Model Pembelajaran Kooperatif Tipe Student Teams Achievement Division (STAD) dengan Team Game Tournament (TGT) di SD Islam Khalifah Annizam. Jurnal Bina Gogik.2(1):38-48.

[8] Narwoko, J. Dwi dan Suryanto, Bagong.2007. Sosiologi Teks Pengantar Dan Terapan. Jakarta: Kencana Prenada Media Group.

[9] Putri, Saras Utami dan Harini, Esti.2014. Meningkatkan Minat Belajar Matematika Melalui Team Games Tournament Siswa Kelas III MI Muhammadiyah Ngadipuro I Dukun Magelang. UNION: Jurnal Pendidikan Matematika.2(2):191-196.

[10] Slavin, Robert E.. 2015. Cooperative Learning Teori, Riset, dan Praktik. (Alih bahasa: Narulita Yusron). Bandung: Nusa Media.

[11] Wijayanti, A. (2016). Implementasi model pembelajaran kooperatif tipe TGT sebagai upaya meningkatkan pemahaman konsep fisika dasar mahasiswa pendidikan IPA. Jurnal Pijar Mipa, 11(1). 